\title{
Effect of Treatment with Licorice Solution on the Dormancy and Sprouting of Tubers of Some Potato Varieties
}

\author{
${ }^{1 *}$ Dr. Rida DRAIE, ${ }^{2}$ Abdul-Mohsen AL-ALI \\ ${ }^{1}$ Faculty of Agricultural Engineering, University of Idlib, Syria \\ ${ }^{2}$ Postgraduate Student, MA, Faculty of Agricultural Engineering, University of Idlib, Syria \\ *Corresponding Author Email: ridadraie@ hotmail.com
}

\begin{abstract}
This research was conducted in order to study the effect of treatment with licorice solution on the dormancy and sprouting of tubers of three potato varieties, Spunta, Synergy, and Panela. The research was carried out in the 2019 agricultural season in the Sahel alRouj region in northern Syria. Tubers were treated with licorice solution at four concentrations $(0,5,10$, and $20 \mathrm{~g} / \mathrm{l})$ and during four periods $(0,1,2,3$ hours). The results showed that all treatments with licorice were superior to the control, the highest concentration ( $20 \mathrm{~g} / \mathrm{L})$ was superior to the other concentrations, and the longest soaking period ( 3 hours) was superior to the other soaking periods, in all the studied traits. Generally, soaking the tubers of the Panela variety with yeast solution at the concentration of $20 \mathrm{~g} / \mathrm{L}$ and the period of 3 hours achieved the largest number of sprouts per tuber ( 2 sprouts), the major number of basal sprouts (1.38 sprouts), the highest weight of one sprout $(7.50 \mathrm{~g})$, the highest weight of sprouts per tuber (15 g). And the highest weight of sprouts per sample $(60 \mathrm{~g})$. While soaking of Spunta variety tubers with the licorice solution at $20 \mathrm{~g} / \mathrm{L}$ and the period of 3 hours gave the fastest break of the dormancy phase ( 26 days), and the highest daily growth rate $(0.25 \mathrm{~cm} /$ day $)$. Whereas soaking the tubers of Synergy variety with the yeast solution of concentration of $20 \mathrm{~g} / \mathrm{L}$ and the period of 3 hours gave the highest number of sprouts per sample (8.11 sprouts), and the highest number of apical sprouts (8.11 sprouts).
\end{abstract}

Keywords: Licorice, Potato, Sprouting, Tuber Dormancy, Treatment.

\section{INTRODUCTION}

Potatoes are propagated by planting tubers, but when the tubers mature and reach their final sizes, they enter a dormancy phase, in which the tuber buds are not able to sprout even if they are given the right conditions (Lang et al., 1987; Van-Ittersum, 1992; Struik and Wiersema, 1999). Dormancy usually ranges from 6-10 weeks, the length of which depends largely on genetic factors (species or varieties), and to a small extent on the conditions accompanying the growth stage of the tubers (Davidson, 1958; Wurr and Allen, 1976; Burton, 1978). Temperature, humidity, photoperiod during growth and storage are important environmental factors that regulate sprouts behavior (Uwe, 2001; Ezekiel and Singh, 2003). Tuber maturity at harvest, harvest injuries or diseases and pests, and exposure to internal and applied dormancy compounds also play a role in the length of dormancy (Aksenova et al., 2013; Muthoni et al., 2014). Quantitative trait locus (QTL) analysis revealed that tuber dormancy is a quantitative genetic trait (Kotch et al., 1992) and is controlled by nine distinct chromosomal loci either independently or through overlapping interactions (Freyre et al., 1994; Ewing, 1995; Van-Den-Berg et al., 1996; Draie and Al-Absi 2019).

Recent studies have shown the possibility of using plant extracts in order to preserve the environment, and as alternatives to industrial growth regulators and chemical fertilizers because they are natural materials. One of the environmentally friendly materials is licorice. Licorice is a perennial herbaceous plant belonging to the legume family, found in the wild on the banks of rivers. Its roots contain glycosidic substances, glucose sugar, pigments, mineral elements such as calcium, magnesium phosphate, volatile oil, glyceric acid, triterpene saponins, which are glycyrrhizin or glyceric acid with a percentage of $4-24 \%$. It also contains isoflavones, coumarins and asparagine. (Sabry et al., 2009).

Licorice extract has been used in many agricultural studies and experiments to improve the growth and productivity of plants such as tomatoes (Saadoun et al., 2004), cucumbers (Hussein and Al-Rikabi, 2006), and onions (Al-Khafaji and Al-Jubouri, 2010; Ghallum and Faraj, 2012; Al-Babbilyet al., 2015).

In a study conducted by Matar et al. (2012), to determine the effect of immersion of tubers (Burain variety) before planting with licorice extract at a concentration of $5 \mathrm{~g} / \mathrm{L}$, and the effect of foliar spraying with licorice extract at a concentration of $5 \mathrm{~g} / \mathrm{L}$ (once spraying, twice spraying, threetime spraying), in stimulation of bud sprouting, growth and productivity of potato plants compared to the untreated control. The treatment of immersion of tubers with licorice extract was superior to the percentage of dry matter and starch 
ISSN (online): 2581-3048

Volume 5, Issue 7, pp 26-36, July-2021

https://doi.org/10.47001/IRJIET/2021.507005

in tubers, while there was no significant effect of immersion treatments on dry weight of shoots, number of tubers per plant, nitrogen and protein ratio in tubers. Also, spraying with licorice extract had a significant effect on plant height, plant dry weight, potassium percentage in leaves, nitrogen and protein percentage in tubers, as well as giving the highest rate of total potato production.

Breaking dormancy is of great importance when planting potato tubers, as well as when importing newly plucked tubers and planting them directly, and when wanting to sprout tubers to test that they are free of diseases before proving their suitability for sowing. Given the importance of cultivating potatoes in the autumn grove, which constitutes more than $50 \%$ of the total cultivated area in Syria, and the farmers' use of spring grouse tubers as seeds before the end of the dormancy phase in planting the autumn grove, the importance of the research is manifested in finding an easy, effective and economic way to end the dormancy in tubers intended for planting in the autumn grove. Therefore, in this research, we will test the effect of treatment with several concentrations and several periods with licorice solution in breaking the dormancy of tubers of some locally grown potato varieties.

\section{MATERIALS AND METHODS}

\subsection{Experimental Location}

The study was carried out in the agricultural season 2019, in Idlib countryside, where tubers were transferred after treatment to special rooms with low lighting and high humidity, with temperatures of about $25^{\circ} \mathrm{C}$.

\subsection{Plant Materials}

Three varieties are used in this research:

- Spunta: a medium early-ripening Danish variety, with elongated tubers, large size, smooth surface, short dormancy period and very shallow eyes.
- Panela: a fast-growing and ripening Dutch variety, the tubers are large elongated spherical.

- Synergy: a variety imported from a French company. Its tubers are elongated, medium to large size, with a medium dormancy period.

\subsection{Experimental Design and treatments}

The research was carried out on three varieties, which are Spunta, Synergy, and Panela. The tubers were treated with licorice solution at four concentrations $(0,5,10$, and $20 \mathrm{~g} / \mathrm{L})$ during four soaking periods ( $0,1,2$, and 3 hours). The complete randomized design (CRD) was used in the experiment with 3 replicates per treatment and each replicate was one $\mathrm{kg}$ tubers. Consequently, the total number of treatments used in the experimentation $=3$ varieties $\mathrm{x} 4$ concentrations $\times 4$ soaking periods $\times 3$ replicates $=144$ treatments (144 $\mathrm{kg}$ potato tubers).

\subsection{Measured Parameters}

The following measurements were taken:

- The number of days until sprouting on tubers (length of dormancy).

- The number of sprouts on the tuber (sprouts per tuber).

- The number of sprouts on the sample (sprouts/1 kg tubers).

- The number of apical sprouts.

- The number of basal sprouts.

- The daily growth rate of sprout $(\mathrm{cm})$.

- Average weight of one sprouts (g).

- Total weight of sprouts per tuber $(\mathrm{g})$.

- Weight of total sprouts per sample (g/1 kg tubers).

\subsection{Statistical analysis}

The results were analyzed by the statistical program (GenStat-12). The averages were compared by testing the least significant difference (LSD) at 5\% significance level.

\section{RESULTS AND DISCUSSION}

\subsection{Effect of one independent factor on the studied traits}

\subsubsection{Effect of the treatment with the licorice}

Table (1): Effect of treatment with licorice on the studied traits

\begin{tabular}{|c|c|c|c|}
\hline Treatment & Control & licorice & $\mathbf{L S D}_{0.05}$ \\
\hline Days until sprouting & $42.83^{\mathrm{b}}$ & $27.96^{\mathrm{a}}$ & 1.33 \\
\hline Number of sprouts per tuber & $0.63^{\mathrm{b}}$ & $1.16^{\mathrm{a}}$ & 0.27 \\
\hline Number of sprouts per sample & $3.34^{\mathrm{b}}$ & $6.45^{\mathrm{a}}$ & 1.01 \\
\hline Number of apical sprouts & $3.38^{\mathrm{b}}$ & $6.22^{a}$ & 0.73 \\
\hline
\end{tabular}


ISSN (online): 2581-3048

\begin{tabular}{|l|l|l|l|}
\hline Number of basal sprouts & $0.08^{\mathrm{b}}$ & $0.23^{\mathrm{a}}$ & 0.44 \\
\hline Daily growth rate of sprout (cm) & $0.08^{\mathrm{b}}$ & $0.15^{\mathrm{a}}$ & 0.05 \\
\hline A verage weight of one sprout $(\mathrm{g})$ & $0.88^{\mathrm{b}}$ & $4.99^{\mathrm{a}}$ & 0.63 \\
\hline Weight of sprouts per tuber $(\mathrm{g})$ & $1.46^{\mathrm{b}}$ & $6.27^{\mathrm{a}}$ & 1.13 \\
\hline Weight of total sprouts per sample & $4.32^{\mathrm{b}}$ & $32.78^{\mathrm{a}}$ & 2.34 \\
\hline
\end{tabular}

The results of the statistical analysis in Table (1) showed that the treatment with the licorice was significantly superior to the control in all the studied traits, as the tubers began to sprout at 15 days in advance (27.96 days for the licorice treatments and 42.83 days for the control). The number of sprouts on the tuber increased by $84 \%$ (1.16 sprouts in the licorice treatments and 0.63 sprouts in the control), the number of sprouts per sample by $93 \%$ (6.45 sprouts in the licorice treatments and 3.34 sprouts in the control), the number of apical sprouts by $84 \%$ (6.22 sprouts in licorice treatments and 3.38 sprouts in control), and the number of basal sprouts increased by $187.5 \%$ ( 0.23 sprouts in licorice treatments and 0.08 sprouts in control). The daily growth rate increased by $87.5 \%(0.15 \mathrm{~cm}$ in the licorice treatments and $0.08 \mathrm{~cm}$ in the control), the weight of one sprout increased by $467 \%$ (4.99 $\mathrm{g}$ in the licorice treatments and $0.88 \mathrm{~g}$ in the control), the weight of the sprouts on the tuber increased by $329 \%$ (6.27 $\mathrm{g}$ in the licorice treatments and $1.46 \mathrm{~g}$ in the control), and the weight of the sprouts per sample increased by $658 \%$ (32.78 $\mathrm{g}$ in the licorice treatments and $4.32 \mathrm{~g}$ in the control).
Our results are consistent with the results of previous studies conducted with the aim of knowing the importance of the treatment with licorice extract in the sprouting of potato tubers. In a study carried out by Matar et al. (2012) in the Iraq Ramadi city, to study the effect of immersion of tubers (Burain variety) before planting with gibberellin solution at a concentration of $5 \mathrm{mg} / \mathrm{L}$ and licorice extract at a concentration of $5 \mathrm{~g} / \mathrm{L}$, and to study the effect of foliar spraying with licorice extract at a concentration of $5 \mathrm{~g} / \mathrm{L}$ (once spraying, twice spraying, and three-time spraying), in stimulating bud sprouting, growth and productivity of potato plants compared to the untreated control. Sprayingwith licorice extract on the vegetative part significantly affected plant height, plant dry weight, potassium percentage in leaves, nitrogen and protein percentage in tubers, as well as gave the highest rate of total potato production and marketable production for all spraying treatments that did not differ significantly among them in these traits compared to the control.

\subsubsection{Effect of the variety}

Table (2): Effect of the variety on the studied traits

\begin{tabular}{|l|c|c|c|c|}
\hline \multicolumn{1}{|c|}{ Variety } & Spunta & Synergy & Panela & LSD $_{0.05}$ \\
\hline Traits & $24.75^{\mathrm{a}}$ & $28.33^{\mathrm{c}}$ & $26.56^{\mathrm{b}}$ & 1.56 \\
\hline Days until sprouting & $1.65^{\mathrm{a}}$ & $1.06^{\mathrm{c}}$ & $1.29^{\mathrm{b}}$ & 0.23 \\
\hline Number of sprouts per tuber & $8.78^{\mathrm{a}}$ & $8.13^{\mathrm{a}}$ & $5.99^{\mathrm{b}}$ & 1.08 \\
\hline Number of sprouts per sample & $7.91^{\mathrm{a}}$ & $7.49^{\mathrm{a}}$ & $5.51^{\mathrm{b}}$ & 0.91 \\
\hline Number of apical sprouts & $0.87^{\mathrm{a}}$ & $0.63^{\mathrm{a}}$ & $0.48^{\mathrm{a}}$ & 0.43 \\
\hline Number of basal sprouts & $0.19^{\mathrm{a}}$ & $0.13^{\mathrm{a}}$ & $0.15^{\mathrm{a}}$ & 0.06 \\
\hline Daily growth rate of sprout $(\mathrm{cm})$ & $5.03^{\mathrm{b}}$ & $4.28^{\mathrm{c}}$ & $6.85^{\mathrm{a}}$ & 0.62 \\
\hline A verage weight of one sprout $(\mathrm{g})$ & $8.33^{\mathrm{a}}$ & $4.67^{\mathrm{b}}$ & $8.94^{\mathrm{a}}$ & 1.09 \\
\hline Weight of sprouts per tuber $(\mathrm{g})$ & $45.44^{\mathrm{a}}$ & $35.04^{\mathrm{b}}$ & $39.70^{\mathrm{a}} \mathrm{b}$ & 3.67 \\
\hline Weight of total sprouts per sample & & & & \\
\hline
\end{tabular}

Table (2) shows the superiority of the Spunta variety in the number of days until sprouting, significantly over the Panela variety, which was significantly superior to the Synergy variety, as the sprouts appeared after 24.75, 26.56 and 28.33 days, respectively. Also, the Spunta variety was significantly superior in the number of sprouts per tuber, over the Panela variety, which was significantly superior on the Synergy variety. The number of sprouts per tuber was $1.65,1.29$ and 1.06, respectively. Table (2) shows the superiority of each of the two varieties, Spunta and Synergy, in the number of sprouts per sample, significantly over the variety Panela, with no significant differences between them, as the number of sprouts per sample was $8.78,8.13$ and 5.99 for the variety Spunta, Synergy, and Panela, respectively. Also, there were no differences between the two varieties, Spunta and Synergy, in the number of apical sprouts, and it was superior to the variety Panela, where the number of sprouts reached 7.91, 7.49 and 5.51 for the varieties Spunta, Synergy, and Panela respectively. There were no significant differences between the studied varieties in the number of basal sprouts per tuber, as the number of basal sprouts was $0.87,0.63$ and 0.48 for the varieties Spunta, Synergy, and Panela, respectively. Also, there were no significant differences between the studied varieties in the daily growth rate of sprouts, as the rate was 
ISSN (online): 2581-3048

$0.19,0.15$ and $0.13 \mathrm{~cm} /$ day for the varieties Spunta, Panela and Synergy, respectively. Table (2) indicates the superiority of the variety Panela over the two varieties, Spunta and Synergy, as well as the superiority of the variety Spunta over the variety Synergy in the characteristic of sprout weight, as the sprout weight reached 5.03, 4.28 and $6.85 \mathrm{~g}$ for the varieties Spunta, Synergy and Panela respectively. The results of the statistical analysis according to Table (2) showed that the two varieties Spunta and Panela were significantly superior in the weight of sprouts per tuber over the variety Synergy (there were no significant differences between the two varieties Spunta and Panela), and the weights were 8.33, 4.67 and $8.94 \mathrm{~g}$ in the varieties Spunta, Synergy, and Panela respectively. Through Table (2), we notice the superiority of the Spunta variety over the Synergy variety the weight of the sprouts per sample, while there were no significant differences between the Spunta variety and the Panela variety on the one hand, and the Panela variety and Synergy on the other hand, and the weight of the sprouts per sample was 45.44, 35.04 and $39.70 \mathrm{~g}$ for the varieties Spunta, Synergy, and Panela, respectively.

Through the previous results, the effect of the genetic factor on the studied traits and parameters is evident, as the Spunta variety surpassed the other varieties, Synergy, and Panela, especially in the characteristic of dormancy-breaking and sprouting, as the dormancy in the Spunta variety ended two days before the Synergy variety and four days before the
Panela variety despite applying the same treatments to all varieties. These results confirm the effect of the genetic factor on the dormancy of potato tubers and are consistent with previous studies that talked about the role of the genetic factor as one of the most important dormancy factors in tubers (Suttle, 2007; Muthoni et al., 2014). It also agrees with the findings of Nasiruddin et al. (2016) who showed the difference of the studied potato varieties among themselves in the dormancy period of the tubers and in the degree of the effect of the treatments in breaking the dormancy phase and in all the studied traits depending on the variety on which the treatment was applied. As for the size and weight of the tubers, and inversely proportional to the length of the dormant period (Krijthe, 1958; Suttle, 2007), our results were contrary to what was discussed in the aforementioned studies. Where the variety Spunta surpassed the two varieties Synergy and Panela despite the fact that the tubers are smaller and less weight. This can be explained and linked to the genetic factor, as the size of the tubers affects the length of the dormancy period when the tubers belong to the same variety and thus the degree of maturity (which is less in the young tubers) plays a role in the dormancy period, while in our case the smaller tubers belong to another variety that is characterized by a less dormant period (with the fact that these tubers have reached the stage of biological maturity), and therefore the differences in the dormancy period between the studied varieties are mainly due to the influence of the genetic factor.

\subsubsection{Effect of the treatment concentration}

Table (3): Effect of treatment concentration on the studied traits

\begin{tabular}{|l|c|c|c|c|c|}
\hline \multicolumn{1}{|c|}{ Concentration $(\mathrm{g} / \mathrm{L})$} & $\mathbf{0}$ & 5 & 10 & 20 & $\mathrm{LSD}_{0.05}$ \\
\hline Traits & $42.83^{\mathrm{c}}$ & $27.56^{\mathrm{b}}$ & $26.44^{\mathrm{a}}$ & $25.64^{\mathrm{a}}$ & 0.87 \\
\hline Days until sprouting & $0.63^{\mathrm{d}}$ & $1.20^{\mathrm{c}}$ & $1.33^{\mathrm{b}}$ & $1.47^{\mathrm{a}}$ & 0.09 \\
\hline Number of sprouts per tuber & $3.34^{\mathrm{d}}$ & $7.04^{\mathrm{c}}$ & $7.72^{\mathrm{b}}$ & $8.15^{\mathrm{a}}$ & 0.42 \\
\hline Number of sprouts per sample & $3.38^{\mathrm{c}}$ & $6.50^{\mathrm{b}}$ & $7.05^{\mathrm{a}}$ & $7.36^{\mathrm{a}}$ & 0.44 \\
\hline Number of apical sprouts & $0.083^{\mathrm{b}}$ & $0.54^{\mathrm{a}}$ & $0.67^{\mathrm{a}}$ & $0.77^{\mathrm{a}}$ & 0.36 \\
\hline Number of basal sprouts & $0.081^{\mathrm{b}}$ & $0.15^{\mathrm{a}}$ & $0.15^{\mathrm{a}}$ & $0.16^{\mathrm{a}}$ & 0.04 \\
\hline Daily growth rate of sprout $(\mathrm{cm})$ & $0.88^{\mathrm{d}}$ & $4.74^{\mathrm{c}}$ & $5.38^{\mathrm{b}}$ & $6.04^{\mathrm{a}}$ & 0.29 \\
\hline Average weight of one sprout $(\mathrm{g})$ & $1.46^{\mathrm{d}}$ & $5.73^{\mathrm{c}}$ & $7.20^{\mathrm{b}}$ & $9.02^{\mathrm{a}}$ & 0.57 \\
\hline Weight of sprouts per tuber $(\mathrm{g})$ & $4.32^{\mathrm{d}}$ & $33.63^{\mathrm{c}}$ & $39.30^{\mathrm{b}}$ & $47.25^{\mathrm{a}}$ & 3.94 \\
\hline Weight of total sprouts per sample & & & & & \\
\hline
\end{tabular}

It appears from Table (3) that all the treatments of the concentrations $(5,10$, and $20 \mathrm{~g} / \mathrm{L})$ were significantly superior to the control $(0 \mathrm{~g} / \mathrm{L})$ in all the studied traits. The concentration of $20 \mathrm{~g} / \mathrm{L}$ significantly exceeded the other concentrations in the number of sprouts per tuber with 1.47 sprouts, in the number of sprouts per sample with 8.15 sprouts, in the weight of one sprout with $6.04 \mathrm{~g}$, in the weight of the sprouts per tuber with $9.02 \mathrm{~g}$, and in the weight of the sprouts per sample with $47.25 \mathrm{~g}$. The concentration of $20 \mathrm{~g} / \mathrm{L}$ and the concentration $10 \mathrm{~g} / \mathrm{L}$ significantly exceeded the concentration of $5 \mathrm{~g} / \mathrm{L}$ in the number of days until sprouting with values of 25.64 days, 26.44 days and 27.56 days, respectively, and in the number of apical sprouts with 7.36, 7.05 and 6.50 sprouts, respectively. While there were no significant differences between the concentrations 20,10 and $5 \mathrm{~g} / \mathrm{L}$ in the number of basal sprouts (average of 0.66 sprouts) and in the daily growth rate of sprout $(0.15 \mathrm{~cm}$ average $)$. 
ISSN (online): 2581-3048

The previous results showed the positive effect of increasing the concentration in breaking the dormancy phase and accelerating the sprouting of tubers, as it led to a reduction of the dormant period by 17 days at $20 \mathrm{~g} / \mathrm{L}, 16$ days at $10 \mathrm{~g} / \mathrm{L}$, and 15 days at $5 \mathrm{~g} / \mathrm{L}$. These results are consistent with previous studies. Alam et al. (1994) showed that increasing the concentration of the treatment material leads to acceleration of sprouting and breaking the dormancy phase of the potato tubers without exceeding the critical level (which is the limit at which the negative effects of the treatment begin to appear).
Also, Coleman and McIcerney (1997) and Coleman (1998) showed that higher concentrations were more effective and led to breaking-dormancy faster than lower concentrations. In a study conducted by Chindi and Tsegaw (2020), they showed that the higher concentrations were more influential on the studied traits. Draie and Al-Ali (2021a;b) also showed that increasing the concentration of the treatment leads to faster tubers sprouting and early breakage of the dormancy phase, and that the higher concentration was more effective.

\subsubsection{Effect of the soaking period length}

Table (4): Effect of soaking period length on the studied traits

\begin{tabular}{|l|c|c|c|c|c|}
\hline \multicolumn{1}{|c|}{ Seaking period length (hour) } & 0 & 1 & 2 & 3 & LSD $_{0.05}$ \\
\hline Traits & $42.83^{\mathrm{c}}$ & $27.11^{\mathrm{b}}$ & $26.31^{\mathrm{a}}$ & $26.22^{\mathrm{a}}$ & 0.70 \\
\hline Days until sprouting & $0.63^{\mathrm{c}}$ & $1.15^{\mathrm{b}}$ & $1.38^{\mathrm{a}}$ & $1.47^{\mathrm{a}}$ & 0.10 \\
\hline Number of sprouts per tuber & $3.34^{\mathrm{c}}$ & $6.66^{\mathrm{b}}$ & $7.91^{\mathrm{a}}$ & $8.33^{\mathrm{a}}$ & 0.53 \\
\hline Number of sprouts per sample & $3.38^{\mathrm{d}}$ & $6.09^{\mathrm{c}}$ & $7.14^{\mathrm{b}}$ & $7.68^{\mathrm{a}}$ & 0.52 \\
\hline Number of apical sprouts & $0.08^{\mathrm{b}}$ & $0.56^{\mathrm{a}}$ & $0.76^{\mathrm{a}}$ & $0.65^{\mathrm{a}}$ & 0.19 \\
\hline Number of basal sprouts & $0.08^{\mathrm{b}}$ & $0.15^{\mathrm{a}}$ & $0.15^{\mathrm{a}}$ & $0.17^{\mathrm{a}}$ & 0.04 \\
\hline Daily growth rate of sprout (cm) & $0.88^{\mathrm{d}}$ & $4.90^{\mathrm{c}}$ & $5.39^{\mathrm{b}}$ & $5.86^{\mathrm{a}}$ & 0.28 \\
\hline Average weight of one sprout (g) & $1.46^{\mathrm{d}}$ & $5.74^{\mathrm{c}}$ & $7.50^{\mathrm{b}}$ & $8.71^{\mathrm{a}}$ & 0.60 \\
\hline Weight of sprouts per tuber $(\mathrm{g})$ & $4.32^{\mathrm{d}}$ & $32.10^{\mathrm{c}}$ & $40.66^{\mathrm{b}}$ & $47.42^{\mathrm{a}}$ & 3.75 \\
\hline Weight of total sprouts per sample & & & & &
\end{tabular}

The results shown in Table (4) indicate that all treatment periods $(1,2$, and 3 hours) were significantly superior to the control ( 0 hour) in all the studied traits. The 3 -hour soaking period outperformed the other soaking periods in the number of apical sprouts with $7.68 \mathrm{~g}$, in the weight of one sprout with $5.86 \mathrm{~g}$, in the weight of the sprouts per tuber with $8.71 \mathrm{~g}$, and in the weight of the sprouts per sample with $47.42 \mathrm{~g}$. The 3hour soaking period and the 2-hour soaking period (Without significant differences between them) significantly exceeded the 1-hour soaking period in the number of days until sprouting with values of 26.22 days, 26.31 days, and 27.11 days respectively, in the number of sprouts per tuber with $1.47,1.38$, and 1.15 sprouts, respectively, in the number of sprouts per sample with values of $8.33,7.91$, and 6.66 sprouts, respectively. While there were no significant differences between the soaking periods of 3,2 and 1 hours in the number of basal sprouts (average of 0.66 buds) and the daily growth rate of sprout (an average of $0.16 \mathrm{~cm}$ ).

The previous results demonstrate the importance of all soaking periods in accelerating sprouting and breaking the dormancy phase. They reduced the dormant period by 17 days in the 3-hour period and the 2-hour period, and 16 days in the 1-hour period. Thus, the effect of the length of the treatment period was similar with respect to the dormancy of the tubers, but all the periods reduced the dormant period by a large time compared with control (43 days). These results are consistent with a number of studies that indicated an increase in the percentage of sprouting by increasing the length of treatment.

Draie and Al-Ali (2021a;b) indicated that increasing the length of the treatment period led to faster sprouting of tubers and early breakage of the dormancy phase, and an increase in the number of sprouted shoots, and their daily growth rate and weight. Also, the longer soaking period gave the best results. Similarly, Radi et al. (2013) indicated that the percentage of sprouting increased with the length of the treatment period, and the longer period was the higher of the sprouting percentage. Al-Imam et al. (2016) also showed that increasing the length of the treatment period gave better results and led to an increase in sprouting percentage compared to the other treatments (shorter) and the treatment of the control. While, Al-Saadi (2013) stated that the increase in the length of the treatment period was counterproductive and caused a decrease in the sprouting percentage. These results can be explained by the fact that increasing the length of the treatment period leads to an increase in the sprouting percentage and improvement of the studied traits as long as this period falls below the critical limit, and in the event that the length of the treatment period exceeds the critical limit, it will lead to negative results on the studied traits. 
3.2 Effect of the interaction between the experimental factors on the studied traits

\subsubsection{Number of days until sprouting}

Table (5): Effect of the interaction between the experimental factors on the number of days until sprouting

\begin{tabular}{|c|c|c|c|c|c|}
\hline \multicolumn{3}{|c|}{$\begin{array}{l}\text { Treatment } x \text { Concentration } x \\
\text { Period }\end{array}$} & Panela & Spunta & Synergy \\
\hline \multirow{9}{*}{ Licorice } & \multirow{3}{*}{$5 \mathrm{~g} / \mathrm{L}$} & $1 \mathrm{~h}$ & 29.00 & 28.00 & 29.00 \\
\hline & & $2 \mathrm{~h}$ & 29.00 & 28.00 & 29.00 \\
\hline & & $3 \mathrm{~h}$ & 29.00 & 28.00 & 29.00 \\
\hline & \multirow{3}{*}{$10 \mathrm{~g} / \mathrm{L}$} & $1 \mathrm{~h}$ & 29.00 & 28.00 & 28.00 \\
\hline & & $2 \mathrm{~h}$ & 28.00 & 27.00 & 28.00 \\
\hline & & $3 \mathrm{~h}$ & 28.00 & 27.00 & 28.00 \\
\hline & \multirow{3}{*}{$20 \mathrm{~g} / \mathrm{L}$} & $1 \mathrm{~h}$ & 28.00 & 27.00 & 28.00 \\
\hline & & $2 \mathrm{~h}$ & 28.00 & 27.00 & 27.00 \\
\hline & & $3 \mathrm{~h}$ & 27.00 & 26.00 & 27.00 \\
\hline \multicolumn{3}{|c|}{ LSD (5\%) } & \multicolumn{3}{|c|}{0.16} \\
\hline \multicolumn{3}{|c|}{ C.V. (\%) } & \multicolumn{3}{|c|}{16.8} \\
\hline
\end{tabular}

The results of the statistical analysis of the interaction between the experimental factors outweigh the interaction of the Spunta variety with the concentration of $20 \mathrm{~g} / \mathrm{L}$ of the licorice solution within the 3-hour soaking period in the breaking of dormant phase and sprouting, with an average 26 days after treatment, where the differences were significant, (Table 5).

\subsubsection{Number of sprouts per tuber}

Table (6): Effect of the interaction between the experimental factors on the number of sprouts per tuber

\begin{tabular}{|c|c|c|c|c|c|}
\hline \multirow{2}{*}{\multicolumn{3}{|c|}{$\begin{array}{l}\text { Treatment } x \quad \text { Cencentration } x \\
\text { Period }\end{array}$}} & \multirow{3}{*}{$\begin{array}{l}\text { Panela } \\
1.10\end{array}$} & \multirow{3}{*}{$\begin{array}{l}\text { Spunta } \\
0.80\end{array}$} & \multirow{3}{*}{$\begin{array}{l}\text { Synergy } \\
\qquad 0.80\end{array}$} \\
\hline & & & & & \\
\hline \multirow{9}{*}{ Licorice } & \multirow{3}{*}{$5 \mathrm{~g} / \mathrm{L}$} & $1 \mathrm{~h}$ & & & \\
\hline & & $2 \mathrm{~h}$ & 1.20 & 0.90 & 0.80 \\
\hline & & $3 \mathbf{h}$ & 1.30 & 1.00 & 0.90 \\
\hline & \multirow{3}{*}{$10 \mathrm{~g} / \mathrm{L}$} & $1 \mathrm{~h}$ & 1.20 & 1.00 & 0.90 \\
\hline & & $2 \mathrm{~h}$ & 1.30 & 1.20 & 0.90 \\
\hline & & $3 \mathrm{~h}$ & 1.40 & 1.30 & 1.00 \\
\hline & \multirow{3}{*}{$20 \mathrm{~g} / \mathrm{L}$} & $1 \mathrm{~h}$ & 1.50 & 1.20 & 1.00 \\
\hline & & $2 \mathrm{~h}$ & 1.80 & 1.30 & 1.10 \\
\hline & & $3 \mathbf{h}$ & 2.00 & 1.40 & 1.10 \\
\hline \multicolumn{3}{|c|}{ LSD (5\%) } & \multicolumn{3}{|c|}{0.027} \\
\hline \multicolumn{3}{|c|}{ C.V. (\%) } & \multicolumn{3}{|c|}{12.5} \\
\hline
\end{tabular}

Table (6) shows the superiority of the interaction of the Panela variety with the $20 \mathrm{~g} / \mathrm{L}$ concentration of licorice solution within the 3 -hour soaking period in the number of sprouts per tuber with an average of 2 sprouts, where the differences were significant from the other interactions.

\subsubsection{Number of sprouts per sample}

Table (7): Effect of the interaction between the experimental factors on the number of sprouts per sample

\begin{tabular}{|c|c|c|c|c|c|}
\hline \multicolumn{3}{|c|}{$\begin{array}{c}\text { Variety } \\
\text { Treatment } x \text { Concentration } x\end{array}$} & \multirow[b]{2}{*}{ Panela } & \multirow[b]{2}{*}{ Spunta } & \multirow[b]{2}{*}{ Synergy } \\
\hline $\begin{array}{l}\text { Treatment } \\
\text { Period }\end{array}$ & $x$ Con & tion $x$ & & & \\
\hline \multirow{7}{*}{ Licorice } & \multirow{3}{*}{$5 \mathrm{~g} / \mathrm{L}$} & $1 \mathrm{~h}$ & 5.50 & 4.72 & 6.08 \\
\hline & & $2 \mathrm{~h}$ & 5.88 & 5.22 & 6.08 \\
\hline & & $3 \mathrm{~h}$ & 6.11 & 5.50 & 6.78 \\
\hline & \multirow{3}{*}{$10 \mathrm{~g} / \mathrm{L}$} & $1 \mathrm{~h}$ & 5.61 & 5.40 & 6.78 \\
\hline & & $2 \mathrm{~h}$ & 5.98 & 6.48 & 6.78 \\
\hline & & $3 \mathrm{~h}$ & 6.19 & 6.79 & 7.50 \\
\hline & $20 \mathrm{~g} / \mathrm{L}$ & $1 \mathrm{~h}$ & 6.48 & 6.21 & 7.40 \\
\hline
\end{tabular}


ISSN (online): 2581-3048

Volume 5, Issue 7, pp 26-36, July-2021

https://doi.org/10.47001/IRJIET/2021.507005

\begin{tabular}{|c|c|c|c|c|}
\hline & 2 h & 7.20 & 6.50 & 8.05 \\
\cline { 4 - 5 } & 3 h & 8.00 & 6.89 & $\mathbf{8 . 1 1}$ \\
\hline LSD (5\%) & & $\mathbf{0 . 0 5 8}$ & \\
\hline C.V. (\%) & & 4.7 & \\
\hline C.V. (\%) & & $\mathbf{4 . 7}$ & \\
\hline
\end{tabular}

Table (7) shows the superiority of the interaction of the Synergy variety with the $20 \mathrm{~g} / \mathrm{L}$ concentration of licorice solution within the 3-hour soaking period in the number of sprouts per weight unit (sample of one $\mathrm{kg}$ ) with an average of 8.11 sprouts, anywhere the differences were significant from the other interactions.

\subsubsection{Number of apical sprouts}

Table (8): Effect of the interaction between the experimental factors on the number of apical sprouts

\begin{tabular}{|c|c|c|c|c|c|}
\hline \multicolumn{3}{|c|}{ Variety } & \multirow[b]{2}{*}{ Panela } & \multirow[b]{2}{*}{ Spunta } & \multirow[b]{2}{*}{ Synergy } \\
\hline $\begin{array}{l}\text { Treatment } \\
\text { Period }\end{array}$ & & tion $x$ & & & \\
\hline \multirow{9}{*}{ Licorice } & \multirow{3}{*}{$5 \mathrm{~g} / \mathrm{L}$} & $1 \mathrm{~h}$ & 5.50 & 4.72 & 6.08 \\
\hline & & $2 \mathrm{~h}$ & 5.88 & 5.22 & 6.08 \\
\hline & & $3 \mathbf{~ h}$ & 6.11 & 5.50 & 6.78 \\
\hline & \multirow{3}{*}{$10 \mathrm{~g} / \mathrm{L}$} & $1 \mathrm{~h}$ & 5.38 & 5.40 & 6.78 \\
\hline & & $2 \mathrm{~h}$ & 5.11 & 6.48 & 6.78 \\
\hline & & $3 \mathrm{~h}$ & 4.81 & 6.76 & 7.50 \\
\hline & \multirow{3}{*}{$20 \mathrm{~g} / \mathrm{L}$} & $1 \mathrm{~h}$ & 5.49 & 6.21 & 7.40 \\
\hline & & $2 \mathrm{~h}$ & 6.30 & 5.89 & 8.05 \\
\hline & & $3 \mathrm{~h}$ & 6.68 & 6.89 & 8.11 \\
\hline & \multicolumn{2}{|c|}{ LSD (5\%) } & \multicolumn{3}{|c|}{0.035} \\
\hline & \multicolumn{2}{|c|}{ C.V. $(\%)$} & \multicolumn{3}{|c|}{3.1} \\
\hline
\end{tabular}

The results in the Table (8) show the superiority of the interaction of the variety Synergy with the $20 \mathrm{~g} / \mathrm{L}$ concentration of the licorice solution within the 3-hour soaking period in the number of apical sprouts, with an average of 8.11 sprouts, as the differences were significant from the other interactions.

\subsubsection{Number of basal sprouts}

Table (9): Effect of the interaction between the experimental factors on the number of basal sprouts

\begin{tabular}{|c|c|c|c|c|c|}
\hline \multicolumn{3}{|c|}{$\begin{array}{l}\text { Treatment } x \text { Concentration } x \\
\text { Period }\end{array}$} & \multirow{2}{*}{$\begin{array}{l}\text { Panela } \\
0.00\end{array}$} & \multirow{2}{*}{$\begin{array}{l}\text { Spunta } \\
\text { 0.00 }\end{array}$} & \multirow{2}{*}{$\begin{array}{l}\text { Synergy } \\
0.00\end{array}$} \\
\hline \multirow{9}{*}{ Licorice } & \multirow{3}{*}{$5 \mathrm{~g} / \mathrm{L}$} & $1 \mathrm{~h}$ & & & \\
\hline & & $2 \mathrm{~h}$ & 0.00 & 0.00 & 0.00 \\
\hline & & $3 \mathrm{~h}$ & 0.00 & 0.00 & 0.00 \\
\hline & \multirow{3}{*}{$10 \mathrm{~g} / \mathrm{L}$} & $1 \mathrm{~h}$ & 0.30 & 0.00 & 0.00 \\
\hline & & $2 \mathrm{~h}$ & 0.89 & 0.00 & 0.00 \\
\hline & & $3 \mathrm{~h}$ & 1.31 & 0.00 & 0.00 \\
\hline & \multirow{3}{*}{$20 \mathrm{~g} / \mathrm{L}$} & $1 \mathrm{~h}$ & 1.00 & 0.00 & 0.00 \\
\hline & & $2 \mathrm{~h}$ & 0.90 & 0.61 & 0.00 \\
\hline & & $3 \mathrm{~h}$ & 1.38 & 0.00 & 0.00 \\
\hline \multicolumn{3}{|c|}{ LSD (5\%) } & \multicolumn{3}{|c|}{0.035} \\
\hline \multicolumn{3}{|c|}{ C.V. $(\%)$} & \multicolumn{3}{|c|}{3.1} \\
\hline
\end{tabular}

The results in the Table (9) show the superiority of the interaction of Panela variety with the 20 g/L concentration of licorice solution within the 3 -hour soaking period in the number of basal sprouts, with an average of 1.38 sprouts. The differences were significant from the other interactions. 
Table (10): Effect of the interaction between the experimental factors on the daily growth rate of sprout

\begin{tabular}{|c|c|c|c|c|c|}
\hline \multicolumn{3}{|c|}{$\begin{array}{l}\text { Treatment } x \text { Concentration } x \\
\text { Period }\end{array}$} & \multirow{2}{*}{$\begin{array}{c}\text { Panela } \\
0.09\end{array}$} & \multirow{2}{*}{$\begin{array}{c}\text { Spunta } \\
0.20\end{array}$} & \multirow{2}{*}{$\begin{array}{c}\text { Synergy } \\
0.10\end{array}$} \\
\hline \multirow{9}{*}{ Licorice } & \multirow{3}{*}{$5 \mathrm{~g} / \mathrm{L}$} & $1 \mathrm{~h}$ & & & \\
\hline & & $2 \mathrm{~h}$ & 0.09 & 0.20 & 0.10 \\
\hline & & $3 \mathrm{~h}$ & 0.10 & 0.20 & 0.10 \\
\hline & \multirow{3}{*}{$10 \mathrm{~g} / \mathrm{L}$} & $1 \mathrm{~h}$ & 0.08 & 0.20 & 0.10 \\
\hline & & $2 \mathrm{~h}$ & 0.10 & 0.20 & 0.20 \\
\hline & & $3 \mathrm{~h}$ & 0.10 & 0.20 & 0.20 \\
\hline & \multirow{3}{*}{$20 \mathrm{~g} / \mathrm{L}$} & $1 \mathrm{~h}$ & 0.09 & 0.20 & 0.20 \\
\hline & & $2 \mathrm{~h}$ & 0.10 & 0.20 & 0.20 \\
\hline & & $3 \mathrm{~h}$ & 0.20 & 0.25 & 0.20 \\
\hline \multicolumn{3}{|c|}{ LSD (5\%) } & \multicolumn{3}{|c|}{0.046} \\
\hline \multicolumn{3}{|c|}{ C.V. (\%) } & \multicolumn{3}{|c|}{29.8} \\
\hline
\end{tabular}

Table 10 shows the superiority of the interaction of the Spunta variety with the $20 \mathrm{~g} / \mathrm{L}$ concentration of licorice solution in the 3-hour soaking period in the daily growth rate of sprout, with an average of $0.25 \mathrm{~cm}$, wherever the differences were significant from the other interactions.

\subsubsection{Weight of one sprout $(g)$}

Table (11): Effect of the interaction between the experimental factors on the weight of one sprout (g)

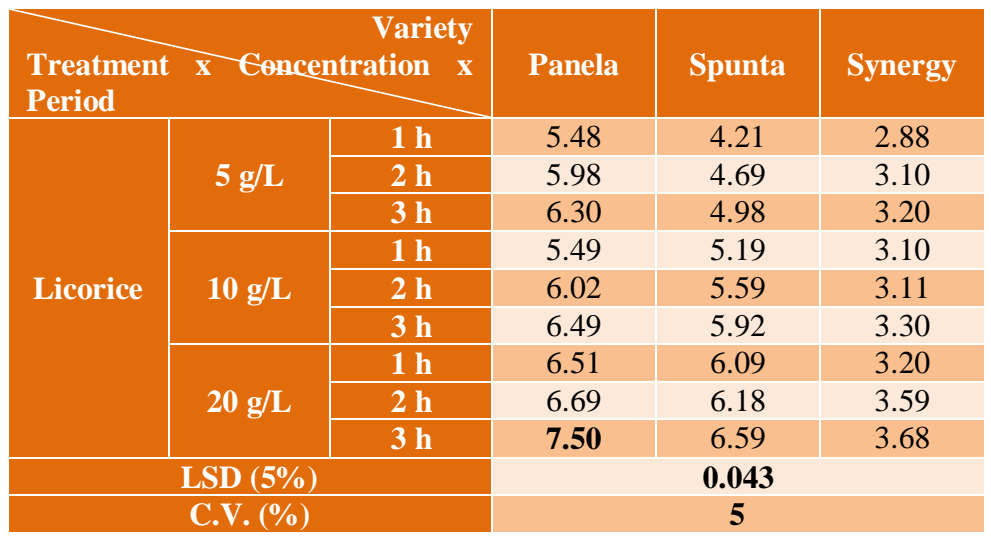

The results in the Table (11) indicate the significant superiority of the interaction of Panela variety with the 20 g/L concentration of licorice solution within the 3-hour soaking period in the average weight of sprout by $7.50 \mathrm{~g}$, on all other interactions.

\subsubsection{Weight of sprouts per tuber}

Table (12): Effect of the interaction between the experimental factors on the weight of sprouts per tuber

\begin{tabular}{|c|c|c|c|c|c|}
\hline \multicolumn{3}{|c|}{$\begin{array}{l}\text { Treatment } x \text { Concentration } x \\
\text { Period }\end{array}$} & Panela & Spunta & Synergy \\
\hline \multirow{9}{*}{ Licorice } & \multirow{3}{*}{$5 \mathrm{~g} / \mathrm{L}$} & $1 \mathrm{~h}$ & 6.08 & 3.39 & 2.30 \\
\hline & & $2 \mathrm{~h}$ & 7.09 & 4.19 & 2.48 \\
\hline & & $3 \mathrm{~h}$ & 7.91 & 5.50 & 2.88 \\
\hline & \multirow{3}{*}{$10 \mathrm{~g} / \mathrm{L}$} & $1 \mathrm{~h}$ & 6.59 & 5.40 & 2.79 \\
\hline & & $2 \mathrm{~h}$ & 7.81 & 7.78 & 2.83 \\
\hline & & $3 \mathrm{~h}$ & 9.09 & 8.89 & 3.30 \\
\hline & \multirow{3}{*}{$20 \mathrm{~g} / \mathrm{L}$} & $1 \mathrm{~h}$ & 9.79 & 7.31 & 3.20 \\
\hline & & $2 \mathrm{~h}$ & 11.99 & 8.00 & 3.92 \\
\hline & & $3 \mathrm{~h}$ & 15.00 & 9.60 & 4.28 \\
\hline \multicolumn{3}{|c|}{ LSD (5\%) } & \multicolumn{3}{|c|}{0.027} \\
\hline \multicolumn{3}{|c|}{ C.V. (\%) } & \multicolumn{3}{|c|}{12.6} \\
\hline
\end{tabular}


ISSN (online): 2581-3048

The results in the Table (12) show the superiority of the interaction of the Panela variety with the $20 \mathrm{~g} / \mathrm{L}$ concentration of licorice solution within the 3-hour soaking period in the weight of sprouts per tuber with an average of $15.00 \mathrm{~g}$. The superiority over the other interactions was significant.

\subsubsection{Weight of sprouts per sample}

Table (13): Effect of the interaction between the experimental factors on the weight of sprouts per sample

\begin{tabular}{|c|c|c|c|c|c|}
\hline \multicolumn{3}{|c|}{$\begin{array}{l}\text { Treatment } \mathrm{x} \text { Concentration } \mathrm{x} \\
\text { Period }\end{array}$} & \multirow{2}{*}{$\begin{array}{l}\text { Panela } \\
30.28\end{array}$} & \multirow{2}{*}{$\begin{array}{l}\text { Spunta } \\
20.00\end{array}$} & \multirow{2}{*}{$\begin{array}{l}\text { Synergy } \\
17.48\end{array}$} \\
\hline \multirow{9}{*}{ Licorice } & \multirow{3}{*}{$5 \mathrm{~g} / \mathrm{L}$} & $1 \mathrm{~h}$ & & & \\
\hline & & $2 \mathrm{~h}$ & 34.59 & 24.30 & 18.88 \\
\hline & & $3 \mathbf{h}$ & 37.32 & 30.28 & 21.60 \\
\hline & \multirow{3}{*}{$10 \mathrm{~g} / \mathrm{L}$} & $1 \mathrm{~h}$ & 30.99 & 29.19 & 20.91 \\
\hline & & $2 \mathrm{~h}$ & 36.02 & 42.01 & 21.21 \\
\hline & & $3 \mathrm{~h}$ & 40.00 & 46.21 & 24.78 \\
\hline & \multirow{3}{*}{$20 \mathrm{~g} / \mathrm{L}$} & $1 \mathrm{~h}$ & 42.01 & 38.01 & 23.68 \\
\hline & & $2 \mathrm{~h}$ & 47.99 & 40.00 & 29.01 \\
\hline & & $3 \mathrm{~h}$ & 60.00 & 47.01 & 31.48 \\
\hline \multirow{2}{*}{\multicolumn{3}{|c|}{$\frac{\operatorname{LSD}(5 \%)}{\text { C.V. }(\%)}$}} & \multirow{2}{*}{\multicolumn{3}{|c|}{0.296}} \\
\hline & & & & & \\
\hline
\end{tabular}

Table (13) displays the significant superiority of the interaction of the Panela variety with the $20 \mathrm{~g} / \mathrm{L}$ concentration of licorice solution within the 3-hour soaking period, in the weight of sprouts per weight unit (sample of one $\mathrm{kg}$ ) with an average of $60.00 \mathrm{~g}$.

The previous results show the importance of the interaction between the experimental factors in influencing the studied traits, whereas the Panela variety treatments outperformed most of the studied traits (the effect of the genetic factor), the higher concentration treatments $(20 \mathrm{~g} / \mathrm{L})$, and the longer soaking period ( 3 hours) were superior in all the studied traits. Wefind that the interaction of the variety Panela with the soaking period of 3 hours in licorice solution and the concentrations of $20 \mathrm{~g} / \mathrm{L}$ outperformed the other interactions in the number of sprouts per tuber, in the number of basal sprouts, in the weight of one sprout, in the weight of sprout per tuber, and in the weight of sprouts per sample. Likewise, we find that the interaction of the variety Spunta with the 20 $\mathrm{g} / \mathrm{L}$ concentration of licorice solution, within the 3-hour soaking period outperformed the other interactions in the sprouting velocity (shortest dormant period), and in the daily growth rate. While the interaction of Synergy variety with the concentration of $20 \mathrm{~g} / \mathrm{L}$ of licorice solution and the soaking period of 3 hours exceeded the other interactions in the number of sprouts per sample, and in the number of the apical sprouts.

Licorice extract has been used in many agricultural studies and experiments to develop and improve the growth and productivity of plants (Saadoun et al., 2004; Hussein and AlRikabi, 2006; Al-Khafaji and Al-Jubouri, 2010; Ghallum and Faraj, 2012; Al-Babbilyet al., 2015). The licorice extract is believed to have the same function as a stimulant and growth regulator for many plant species (Matar et al., 2012). AlMarsoumi(1999) indicated that the action of licorice extract is similar to the behavior of gibberellin in stimulating vegetative growth from dormant sprouts, and it works to increase cell division and elongation due to its effect on enzymes for converting complex compounds into simple compounds that the plant benefits from in building the protein materials necessary for growth. He advised using it as a substitute for gibberellin in agricultural operations because it contains mevalonic acid, which is the initiating acid in the synthesis of gibberellin.Muhammad and Al-Younis (1991) also mentioned that licorice extract contains sugars that help reduce cold damage, due to the increase in soluble solids in plant cells, which increases the plant's resistance to its damage.

\section{CONCLUSION}

1) All treatments of soaking with licorice outperformed the control in all the studied characteristics, and led to breaking the dormant phase during a period of 27.96 days, while in the control it was 42.83 days.

2) The treatments of the Spuntavariety exceeded the other treatments in the speed of breaking the dormancy phase (24.75 days), followed by the Panela variety (26.56 days), then the Synergy variety (28.33 days).

3) The concentration of $20 \mathrm{~g} / \mathrm{L}$ exceeded the other concentrations and led to breaking the dormancy phase within 25.64 days. Also, the 3-hour soaking period exceeded the other periods and led to breaking the dormancy phase within 26.22 days. 
ISSN (online): 2581-3048

\section{REFERENCES}

[1] Aksenova N.P, Sergeeva L.I, Konstantinova T.N, Golyanovskaya S.A, Kolachevskaya O.O, Romanov G.A. (2013). Regulation of Potato Tuber Dormancy and Sprouting. Russian Journal of Plant Physiology, 60(3): 301-312.

[2] Alam S.M.M, Murr D.P, Kristof L. (1994). The effect of ethylene and of inhibitors of protein and nucleic acid syntheses on dormancy break and subsequent sprout growth. Pot Res., 37: 25-33.

[3] Al-Babbily R., Abu-Turabi B., Jabbour M., Murshid R. (2015). Effect of foliar spraying with licorice root extract and gibberellin on onion plant growth under water stress conditions. The Jordanian Journal of Agricultural Sciences, 11(2): 629-640.

[4] Al-Imam N.M.A, Al-Allaf A.H, Shayal-alalam A.T. (2016). The effect of soaking periods with humic acid on improving seed germination and growth of Eriopotrya japonica seedlings. Al-Furat Journal of Agricultural Sciences, 8(3): 33-41.

[5] Al-Khafaji A.M.H.H., Al-Jubouri K.D.H. (2010). Effect of Organic Fertilizers and Nutrients on Growth and Production of Onion Seeds (Allium cepa L.) Diyala Journal of Agricultural Sciences, 2(2): 64-83.

[6] Al-Marsoumi H.G.K. (1999). Effect of some factors on the characteristics of vegetative growth, flowering and seed yield in three varieties of onions (Allium cepa L.), $\mathrm{PhD}$ thesis, Department of Horticulture, College of Agriculture, University of Baghdad, Iraq.

[7] Al-Saadi N.J.J. (2013). The effect of some treatments on germination of Atropa belladonna seeds. Dyali Journal of Agricultural Sciences, 5(1): 230-235.

[8] Burton W.G. (1978). The physics and physiology of storage. p. 545-606. In: Harris PM (ed) The potato crop. Chapman and Hall, London.

[9] Chindi A, Tsegaw T. (2020). Haulm application and dipping treatments of gibberellic acid on tuber dormancy breaking and sprout induction of potato (Solanum tuberosum L.) in Central Highlands of Ethiopia. International Journal of Plant Physiology and Biochemistry. 12(1): 1-8.

[10] Coleman W.K, Mclcerney J. (1997). Enhanced dormancy release and emergence from potato tubers. Ame Pot J., 74: 173-182.

[11] Coleman W.K. (1998). Carbon dioxide, oxygen and ethylene effects on potato tuber dormancy release and sprout growth. Annals Bot., 82: 21-27.

[12] Davidson T.M.V. (1958). Dormancy in the potato tuber and the effects of storage conditions on initial sprouting and on subsequent sprout growth. Ame Pot J., 35: 451465 .
[13] Draie R, Al-Absi M. (2019). Regulation and Control of Potato Tuber Dormancy and Sprouting. International Journal of Recent Advances in Multidisciplinary Research, 06(01): 4573-4583.

[14] Draie R., Al-Ali A.M. (2021a). Effect of Treatment with Gibberellic Acid on the Dormancy and Sprouting of Tubers of Some Potato Varieties. International Research Journal of Innovations in Engineering and Technology - IRJIET, 5(4): 97-107.

[15] Draie R., Al-Ali A.M. (2021b). Effect of soaking with yeast solution on the dormancy and sprouting of potato tubers. International Research Journal of Innovations in Engineering and Technology - IRJIET, 5(4): 130-141.

[16] Ewing E.E. (1995). The role of hormones in potato (Solanum tuberosum L.) tuberization. p. 698-724. In: Davies PJ (ed) Plant Hormones, Physiology, Biochemistry and Molecular Biology. Kluwer Academic Publication, Dordrecht.

[17] Ezekiel R, Singh B. (2003). Influence of relative humidity on weight loss in potato tubers stored at high temperatures. Indian J Plant Physiol., 8: 141-144.

[18] Freyre R, Warnke S, Sosinski B, Douches D.S. (1994). Quantitative trait locus analysis of tuber dormancy in diploid potato (SoIanum spp.). Theor Appl Gen., 89: 474-480.

[19] Ghallum, A-A.A., Faraj M.A.F. (2012). Effect of foliar spraying and soil supplementation of licorice extract on the growth and production of the Texas Grano Onion, Diala Journal of Agricultural Sciences, 4(1): 140-147.

[20] Hussein W.A., Al-Rikabi, F.H. (2006). Response of cucumber plant (Cucumis sativus L.) to spraying with garlic extract, licorice root and urea on vegetative growth characteristics and plant yield, Iraqi Journal of Agricultural Sciences, 37(4): 33-38.

[21] Kotch G.P, Ortiz R, Peloquin S.J. (1992). Genetic analysis by use of potato haploid populations. Genome, 35: 103-108.

[22] Krijthe N. (1958). Changes in the germinating power of potatoes from the time of lifting onwards. Eur Pot J., 1: 69-72.

[23] Lang G.A, Early J.D, Martin G.C, Darnell R.L. (1987). Endo-, para- and ecodormancy: Physiological terminology and classification for dormancy research. Hort Sci., 22: 371-377.

[24] Matar H.M., Mahmoud S.A-W., Ramadan A.F. (2012). Effect of treatment with yeast and licorice extract on growth and yield of potatoes. Dili Journal of Agricultural Sciences, 4(1): 220-234.

[25] Muhammad A-A.K., Younis M.A. (1991). Fundamentals of Plant Physiology. University of Baghdad, Ministry of Higher Education and Scientific Research, Iraq. 
ISSN (online): 2581-3048

Volume 5, Issue 7, pp 26-36, July-2021 https://doi.org/10.47001/IRJIET/2021.507005

[26] Muthoni J, Kabira J, Shimelis H, Melis R. (2014). Regulation of potato tuber dormancy: A review. Australian Journal of Crop Science, 8(5):754 -759.

[27] Nasiruddin M, Khatun R, Haydar F.M.A, Imtiaj A, Alam M.F. (2016). Effect of physical and chemical treatments on sprouting of dormant potato tubers. Plant Environment Development, 5(2):24-27.

[28] Radi I.M, Kazem A.A, Safana H.S. (2013). Effect of type and duration of typesetting on seed germination and growth of apricot seedlings. Prunus armeniaca L. Muthanna Journal of Agricultural Sciences, 1(1): 6570.

[29] Saadoun, S.A-H., Merza T.K., Razak K.R. (2004). Effect of spraying garlic extract or licorice root with zinc mixture on growth and yield of two tomato cultivars, Iraqi Journal of Agricultural Sciences, 35(1): 35-40.

[30] Sabry G.H., Mervat S., Abd EL-Wahba M.A. (2009). Influence of effective micro-organism, seaweed extract and amino acids application on growth, yield and bunch quality of Red Globe grapevines. J. Agric. Sci. Mansoura Univ. 34: 5901-5921.

[31] Struik P.C, Wiersema S.G. (1999). Seed potato technology. Wageningen University Press. The Netherlands.

[32] Suttle J.C. (2007). Dormancy and Sprouting, Potato Biology and Biotechnology: Advances and Perspectives, Vreugdenhil, D., Ed., Amsterdam: Elsevier, pp. 287-309.

[33] Uwe S. (2001). Control of potato tuber sprouting. Trends in Plant Science, 6: 333-335.

[34] Van-Den-Berg J.H, Ewing E.E, Plaisted R.L, McMurray S, Bonierbale M.W. (1996). QTL analysis of potato tuber dormancy. Theor Appl Gen., 93: 317324.

[35] Van-Ittersum MK. (1992). Variation in the duration of tuber dormancy within a seed potato lot. Eur Pot J., 35: 261-269.

[36] Wurr D.C.E, Allen E.J. (1976). Effects of cold treatments on the sprout growth of three potato varieties. J Agric Sci. (Cambridge), 86: 221-224.

\section{Citation of this Article:}

Dr. Rida DRAIE, Abdul-Mohsen AL-ALI, "Effect of Treatment with Licorice Solution on the Dormancy and Sprouting of Tubers of Some Potato Varieties" Published in International Research Journal of Innovations in Engineering and Technology - IRJIET, Volume 5, Issue 7, pp 26-36, July 2021. Article DOI https://doi.org/10.47001/IRJIET/2021.507005 